\title{
Social Corporatism and Capital Accumulation: The Fate of the Nordic Model
}

The recent crisis of Anglo-Saxon capitalism has generated renewed interest in more cooperative national arrangements, partly in view of the relative resilience of Nordic economies. Strong trade unions operating through coordinated wage bargaining systems combined with developed welfare states appeared capable of delivering successful economic performance with relatively high levels of equality. Much of the recent academic and policy discussion of these arrangements has focused on whether they are effective at achieving sufficient wage flexibility to ensure low rates of unemployment. In earlier work, by contrast, capital accumulation was regarded as central to ensuring growth of wages and employment over the medium and longer term.

\section{The concept of social corporatism}

Corporatism is a multifaceted concept, covering organised systems of wage bargaining, the role of state intermediation and the scope of agreements negotiated in national economies. There is no neat definition of social corporatism, although it has often been identified with Nordic countries. These arrangements typically had their origins in inter-war developments and were institutionalised in post-war settlements. Nordic countries operated strongly coordinated wage bargaining systems, with high levels of union membership. The Nordics have maintained high trade union membership, in contrast to falling density elsewhere, and very extensive coverage of collective agreements. ${ }^{1}$ Similarly, collective organisation of employers remains strong.

Union bargaining had solidaristic objectives in terms of compressing wage differentials among enterprises and

(C) The Author(s) 2018. Open Access: This article is distributed under the terms of the Creative Commons Attribution 4.0 International License (https://creativecommons.org/licenses/by/4.0/), which permits unrestricted use, distribution, and reproduction in any medium, provided you give appropriate credit to the original author(s) and the source, provide a link to the Creative Commons license, and indicate if changes were made.

1 OECD: OECD Employment Outlook 2017, chapter 4, 2017, pp. 125173.

Jonathan Perraton, University of Sheffield, UK. industries. National wage bargaining was to be driven by the sectors exposed to international competition (largely manufacturing in the post-war period), reflecting the evolution of world prices confronting small open economies and the productivity growth in the exposed industries (which were assumed to be the most technologically dynamic). Coordinated bargaining was designed to ensure that wage settlements throughout the economy were set according to rates validated by a capacity to maintain external competitiveness. These arrangements saw the evolution of bargaining regimes between organised labour and businesses combined with relatively egalitarian societies and developed welfare states. ${ }^{2}$ Coordinated wage bargaining systems of this form may mitigate the potential downsides of union power; highly coordinated unions with large memberships have incentives to ensure bargains consistent with high levels of employment, avoiding insider-outsider splits.

The concept of social corporatism is essentially inclusive, with wide coverage of arrangements. All four Nordic economies score relatively highly on Jahn indicators of corporatism, ${ }^{3}$ although these figures have declined for Sweden since the 1980s. Vartiainen argues that the common perception that Nordic countries have moved from highly centralised to more decentralised bargaining systems is somewhat misleading. ${ }^{4}$ Differences between the economies have arisen as they have evolved in the postwar period, yet clear similarities between them remain, as does clear continuity in key aspects over time. Central determination of wage settlements was weaker in practice than sometimes supposed, but strong collective agreements based around norms of external competitiveness remain.

Social corporatism can be distinguished here from competitive or liberal corporatism. Definitions vary, but despite the fact that liberal corporatist regimes have some

2 J.Pekkarinen, M. Pohjola, R. Rowthorn (eds): Social Corporatism: A Superior Economic System?, Oxford 1992, Oxford University Press.

3 D. Jahn: Changing of the guard: Trends in corporatist arrangements in 42 highly industrialized societies from 1960 to 2010, in: Socio-Economic Review, Vol. 14, No. 1, 2016, pp. 47-71.

4 J. Vartiain en: Nordic Collective Agreements - A Continuous Institution in a Changing Economic Environment, in: L. Mjøset (ed.): The Nordic Varieties of Capitalism, Comparative Social Research, Vol. 28, Bingley 2011, Emerald Group Publishing Limited, pp. 331-63. 
degree of coordinated wage bargaining, it may be less centralised than in social corporatist regimes. Crucially, liberal corporatism lacks the egalitarian imperative of social corporatism through solidaristic wage bargaining, and more broadly the pursuit of wider union goals. Austria, for example, had a coordinated wage bargaining system that shared features with Nordic arrangements but that exhibited wider wage dispersion and considerably greater gender inequality. The Dutch Polder model has been taken as an exemplar of new corporatist arrangements that can lead to low unemployment, but solidaristic bargaining is much weaker than it is under social corporatism. Further, negotiated wage moderation in the Netherlands led to a recovery of corporate profitability but without a commensurate revival in investment.

Recently, social pacts have emerged in eurozone countries, but in comparison to social corporatism, these are less egalitarian and associated with weaker social benefits and pay settlements below the productivity growth rate. Furthermore, such arrangements have come under increasing strain, and some have effectively been bypassed under austerity programmes since the global financial crisis. ${ }^{5}$ Nordic social corporatism is thus an alternative not just to Anglo-Saxon liberal capitalism but also to arrangements in other continental European economies.

\section{The role of capital accumulation}

Much of the recent discussion of corporatism has focused on whether coordinated wage bargaining systems can deliver low unemployment through negotiated adjustment. Calmfors and Driffill proposed a hump-shaped relationship between the degree of coordination of wage bargaining and unemployment rates - low unemployment can be achieved in highly decentralised systems, approximating Anglo-Saxon labour markets, but also under highly coordinated corporatist arrangements. ${ }^{6}$ Attempts to test whether corporatist systems actually deliver low levels of unemployment have often been inconclusive, ${ }^{7}$ although some recent studies, including Storm and Naaste-

5 P. Culpepper, A. Regan: Why don't governments need trade unions anymore? The death of social pacts in Ireland and Italy, in: SocioEconomic Review, Vol. 12, No. 4, 2014, pp. 723-45.

6 L. Calmfors, J. Driffill: Bargaining Structure, Corporatism and Macroeconomic Performance, in: Economic Policy, Vol. 3, No. 6 , 1988, pp. 13-61.

7 See e.g. T. Aidt, Z. Tzannatos: Trade unions, collective bargaining and macroeconomic performance, in: Industrial Relations Journal, Vol. 39, No. 4, 2008 pad as well as Sturn, do find evidence that corporatist systems are effective in this capacity. ${ }^{8}$

The focus of recent literature on short-run adjustment misses wider issues here. Investment and capital accumulation remain central to growth in modern economies. Growth in services, as well as in manufacturing, generally requires new investment. Conceptually, economists have separated technological innovation from capital accumulation; in practice, innovation is typically embodied in new equipment. Contrary to some economists' priors, the relative egalitarianism of Nordic economies has not inhibited innovation. Indeed, they are amongst the most innovative economies in the world, ${ }^{9}$ and they also have high levels of ICT investment. Investment in skills is central to modern economies, but skilled workers also require new equipment. Further, investment also leads to lower unemployment over the medium term. ${ }^{10}$

From the standpoint of labour in particular, social corporatist arrangements were not designed simply to achieve high levels of employment through wage restraint. Flexible labour markets of the Anglo-Saxon type can in principle achieve that. Competitive corporatist arrangements may also achieve this, often through keeping wage increases below the rate of productivity growth and reducing employment protection and social security entitlements. In some economic interpretations, corporatism has come to be seen essentially as a device to reduce uncertainty and enable coordination. Earlier interpretations of social corporatism, by contrast, saw investment as central - organised labour would exercise wage restraint in the expectation that the resulting profits would be invested, leading to growth of incomes and employment over the medium and longer term. For organised labour, in particular, the aim here of corporatist strategies was to achieve full employment through high-productivity and high-wage employment.

Bargaining relations between organised labour and firms over time can viewed in terms of non-cooperative games. Workers bargain over wages and firms determine investment (the "right to manage" principle). This can give rise to both the "workers' dilemma" and the "capitalists' di-

8 S. Storm, C. Naastepad: Macroeconomics Beyond the NAIRU, Cambridge MA 2012, Harvard University Press; and S. Sturn: Are Corporatist Labour Markets Different? Labour Market Regimes and Unemployment in OECD Countries, in: International Labour Review, Vol. 152, No. 2, 2013, pp. 237-54.

9 D. Ornston: When small states make big leaps: Institutional innovation and high-tech competition in Western Europe, Ithaca 2012, Cornell University Press.

10 M. Karanassou, H. Sala, P. Salvador: Capital Accumulation and Unemployment: New Insights on the Nordic Experience, in: Cambridge Journal of Economics, Vol. 32, No. 6, 2008, pp. 977-1001. 
lemma". The workers' dilemma is such: if they do not exercise wage restraint, the result will be low profitability and investment, and consequently workers will be unable to realise future increases in income from investment; conversely, though, they have no guarantee that wage restraint will result in sufficient investment to bring about higher future incomes. The capitalists' dilemma is such that they cannot guarantee future returns on their investment, as organised labour may be able to use its bargaining power to appropriate the gains from sunk investments. These two dilemmas lead to sub-optimal capital investment levels, i.e. the "dynamic inefficiency of capitalism".11 Under quite general conditions, it cannot be assumed that the socially optimal solution will arise from repeated bargaining.

There are various possible remedies to this. Under certain conditions, coordinated unions with wide coverage can lead to cooperative solutions which yield higher capital accumulation and thereby higher growth of incomes over the medium and long term. Coordinated unions may be an effective method for delivering nationally negotiated deals - coordination among unions and among different levels of membership within unions may credibly ensure nationally negotiated wage deals are maintained at the local level. Given repeated rounds of bargaining, it may pay for each side to develop a reputation for cooperative behaviour; indeed, Blanchard and Philippon find that Nordic countries have relatively high levels of trust between labour and firms. ${ }^{12}$ Rather than seeking to identify the conditions for a definitive game theoretic solution, historical experience demonstrates that a durable compromise may emerge. Moses points out that the state may play a key intermediary role here. ${ }^{13}$ Governments wish to maintain growth through strong investment and are in a position to offer inducements to each side to cooperate, such as the provision of social benefits for labour and fiscal incentives for investment for firms. This may act to discourage defection, dissuading labour from abandoning wage moderation and helping to induce sustained investment from firms.

Post-war social corporatist arrangements can be seen in these terms. Wage leadership by the exposed sector was sufficiently general in post-war Nordic economies to become known as the Scandinavian model of inflation. This

11 K. Lancaster: The Dynamic Inefficiency of Capitalism, in: Journal of Political Economy, Vol. 81, No. 5, 1973, pp. 1092-1109.

12 O. Blanchard, T. Philippon: The Quality of Labor Relations and Unemployment, NBER Working Paper No. 10590, 2004.

13 J. Moses: The Social Democratic Predicament and Global Economic Integration: A Capital Dilemma, in: W. Coleman, R. Underhill (eds): Regionalism and Global Economic Integration, London 1998, Routledge. would be expected to lead to roughly constant labour and capital shares in income. lacono characterises the essence of the Nordic model in terms of the compression of wage differentials, which leads to productivity growth from creative destruction by fostering the growth of relatively high-productivity enterprises together with high public expenditure. ${ }^{14}$

The most systematic attempt to formalise social corporatist arrangements was through the Rehn-Meidner model proposed by trade unions in post-war Sweden. ${ }^{15}$ Fiscal policy was to be used to restrain inflation and to achieve a public savings surplus. Inflation would lead to higher profit margins and tend to undermine the solidaristic wage bargaining. Under this macroeconomic policy stance, full employment was to be ensured through active labour market policies. This was also central to the proposed role of solidaristic wage policies for structural change. Solidaristic bargaining would lead to wage pressure on less efficient firms whilst benefitting more productive ones; the resulting transfer of labour to more efficient firms would raise nationwide productivity. Expansionary macroeconomic policy could undermine this by allowing firms to raise profit margins and lead to greater wage drift. Thus, the Rehn-Meidner model was predicated on simultaneously maintaining relatively low profit margins and encouraging investment. A restrictive fiscal stance would enable an accumulation of public savings that could be channelled into investment; indirectly, investment was supported by generous tax allowances.

Evidence from Nordic economies provides some support for these expectations. Bengtsson found that although higher union density was associated with higher wage shares in the post-war period, the Nordics were an exception. ${ }^{16}$ However, Sweden diverged somewhat from the rest of the Nordics in this respect, experiencing a squeeze of the profit share over the 1950s and 1960s and then a rise beginning in $1980 .{ }^{17}$ In practice, Martin shows, postwar Sweden saw fluctuations in profit shares and investment levels rather than an entirely orderly exchange of

14 R. Iacono: The Nordic Model of Economic Development and Welfare: Recent Developments and Future Prospects, in: Intereconomics, Vol. 53, No. 4, 2018, pp. 185-190.

15 L. Erixon: Progressive supply-side economics: an explanation and update of the Rehn-Meidner model, in: Cambridge Journal of Economics, Vol. 42, No. 3, 2018, pp. 653-697.

16 E. Bengtsson: Do unions redistribute income from capital to labour? Union density and wage shares since 1960, in: Industrial Relations Journal, Vol. 45, No. 5, 2014, pp. 389-408.

17 E. Bengtsson: Labour's share in twentieth-century Sweden: a reinterpretation, in: Scandinavian Economic History Review, Vol. 62, No. 3, 2014, pp. 290-314. 
wage moderation for high investment. ${ }^{18}$ Nevertheless, Landesmann and Vartiainen observed that over the 196085 period, the Nordic economies maintained relatively high investment even with relatively low profitability. ${ }^{19}$ The economic shocks of the 1970s and 1980s did hit these economies, and they faced increased difficulty in maintaining internal and external balance. However, Nordic economies appeared relatively successful at managing adjustment to these shocks. Henley and Tsakalotos found that social corporatist economies were better able to mitigate pressure on profitability during the 1970s and 1980s slowdown through the management of potential distributional conflict, whilst investment in these economies remained relatively resilient to falls in the profit share over this period. ${ }^{20}$

The weakening economic performance of Nordic countries led some observers to argue that it was no longer possible for these economies to simultaneously maintain the traditional objectives of egalitarian wage bargaining, full employment and fiscal balance. ${ }^{21}$ Despite wage bargaining norms, all Nordic economies except energy-rich Norway required significant devaluations to restore external balance. Structural change led to a fall in employment in the exposed manufacturing sector and a rise in public sector employment, weakening traditional wage leadership arrangements. Iversen argued that the expansion of the public sector reached its limits, with a weakened fiscal position, whilst the compression of wage differentials inhibited the growth of relatively low productivity private services employment. ${ }^{22}$ These changes acted to undermine the Swedish model in ways that the Rehn-Meidner model had been designed to avoid - overheating in the 1980s provided incentives for both firms and skilled workers to defect from coordinated arrangements to the extent that such arrangements reduced firms' discretion to offer higher wages.

Beginning in the 1970s, Swedish employers set out to undermine the post-war model, as Baccaro and Howell set out. ${ }^{23}$ This was partly a response to the unions' Wage-

18 A. Martin: Wages, Profits and Investment in Sweden, in: L. Lindberg, C. Maier (eds.): The Politics of Inflation and Economic Stagnation, Washington DC 1985, Brookings Institution Press.

19 M. Landesmann, J. Vartiainen: Social Corporatism and Longterm Economic Performance, in: J. Pekkarinen et al., op. cit.

20 A. Henley, E. Tsakalotos: Corporatism, Profit Squeeze and Investment, in: Cambridge Journal of Economics, Vol. 15, No. 4, 1991, pp. 425-50.

21 T. Iversen: Contested Economic Institutions: The Politics of Macroeconomics and Wage Bargaining in Advanced Democracies, Cambridge 1999, Cambridge University Press.

22 Ibid.

23 L. Baccaro, C. Howell: Trajectories of neoliberal transformation: European industrial relations since the 1970s, Cambridge 2017, Cambridge University Press.
Earner Fund moves to increase collective share ownership. Employer groups considered this a threat to the "right to manage" principle. Elsewhere amongst the Nordics, as noted, bargaining systems have evolved, but they remain strongly coordinated. Exposed sector wage leadership can still be seen to operate, and employers have continued to participate in corporatist arrangements.

\section{Financial openness and capital accumulation}

Although Nordic economies were thoroughly open to trade in the post-war period, until the 1980s the capital account was more regulated. Policies aimed at net public sector savings meant that although the private corporate sector was typically a net debtor in Sweden and elsewhere, with corporate borrowing and low household savings, this could be funded without recourse to foreign borrowing in the post-war boom. This was in line with the Rehn-Meidner model. A regulated capital account allowed Nordic countries to operate low interest rate policies. Kosonen found key similarities amongst Nordic economies in their savings and investment patterns before the 1980s. ${ }^{24}$

From the 1980s, Nordic economies pursued programmes of rapid financial liberalisation and openness on the capital account. In Finland and Sweden in particular, this led to a credit boom and subsequent bust, with a major banking crisis and recession in the early 1990s. These developments strained the operation of national models, but they may also have longer-term implications.

Evolving bargains over investment effectively assume a financial closed economy. In the theoretical limit case for a small open economy, the capital stock will be determined by the world interest rate and unions cannot affect the real wage. More generally, financial openness in a world of economies with varying levels of union power would be expected to lead to capital outflows from highly unionised economies and to a decline in union bargaining power. ${ }^{25}$ Moses argues that financial liberalisation and integration acts to increase the exit possibilities for capital and thereby acts to weaken the social bargain underwriting investment effort. ${ }^{26}$

The key context here is developments in profitability. Figure 1 shows that the wage share tended to rise in the 1960s and 1970s amongst Nordic economies, although

24 K. Kos onen: Savings and Economic Growth from a Nordic Perspective, in: J. Pekkarinen et al., op. cit.

25 See e.g. M. Aloi, M. Leite-Monteiro, T. Lloyd-Braga: Unionized labor markets and globalized capital markets, in: Journal of International Economics, Vol. 78, No. 1, 2009, pp. 149-153.

26 J. Moses, op. cit. 
Figure 1

\section{Adjusted wage share}

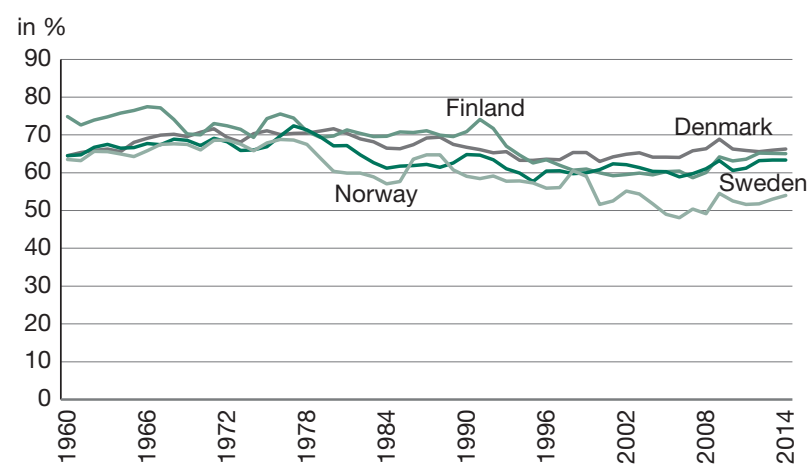

Source: AMECO database.

this was less pronounced than in other European economies. In practice, as noted particularly for the Swedish case, this was not a simple case of exchanging wage moderation for higher investment.

Wage shares have fallen in Nordic countries from the 1980s, although they have stabilised somewhat since 2000. This is consistent with developments in other European economies and beyond. Wage restraint led to a recovery of profit rates and shares to levels comparable with or greater than those seen during the post-war golden age. However, even with this development and the falling real interest rates since the 1980s, weaker investment levels have persisted. Barba and Pivetti highlight that in developed economies, investment has been weak by historic standards, with the corporate sector in many countries becoming a net lender. ${ }^{27}$ This can also be observed in Nordic economies, in contrast to their relatively strong investment performance earlier. In all four cases, investment has fallen as a share of profits relative to earlier in the post-war period. In Denmark, the corporate sector has run surpluses since the 1980s. Finland shows a similar pattern; in the 1970s and 1980s, the corporate sector was typically a significant net borrower, although developments since then are partly due to debt consolidation following the early 1990 s recession. In Norway, the corporate sector balance has fluctuated over time, but again investment as a share of profits has fallen relative to the early post-war period. The Swedish case is similar to Finland, reflecting a similar response to the early 1990s financial crisis and recession, namely corporate consolidation. There has only been a modest recovery in the propensity to invest since the early 1990s downturn.

27 A. Barba, M. Pivetti: Distribution and accumulation in post-1980 advanced capitalism, in: Review of Keynesian Economics, No. 1, 2012, pp. 126-42.
Thus, although wage restraint has generally operated in Nordic economies since the 1980s, this has not led to the investment response seen earlier in the post-war period. There are a number of explanations for this. Financial liberalisation has increased companies' external options, which have in turn increased pressure for shareholder value maximisation. Outward foreign direct investment (FDI) has grown strongly for all these economies. There has also been significant growth of inward FDI into these economies, particularly since 2000 , and firm ownership has become more transnational. Bergholm and Bieler argue that centralised bargaining systems persisted longer in Finland than Sweden because of the greater internationalisation of Swedish companies; however, transnational companies have been actively undermining Finland's bargaining system since 2007.28

\section{Conclusions: The future of the Nordic model}

Repeated reports of the death of the Nordic model have turned out to be exaggerated (and often based on a singular focus on the Swedish case). Economic problems in the 1980 s and 1990s reflected adjustment to a series of shocks; Nordic economies adapted to these shocks, and their subsequent performance does not indicate that their mediumrun growth or unemployment performance is weak.

There is continuity in key aspects of these economies. Union membership is high and bargaining systems remain in place. Inequality has risen but remains comparatively low, and extensive welfare states have been maintained. In the post-war period, Nordic economies developed social corporatist coordinated wage bargaining systems that underpinned their economic performance, combining low unemployment with low levels of inequality. A large body of economic literature has focused on Sweden, where post-war bargaining systems had come under increasing strain and some of their key aspects appeared to have been eroded; in other Nordic economies, however, there has been strong continuity in these systems. In this sense, social corporatist systems remain viable.

Nevertheless, this paper argues that the capital side of the social democratic bargain, largely neglected in recent critical accounts, has been eroded. Despite the recovery of profit rates and shares in these economies (and most OECD countries), there has not been a return to the rates of capital accumulation seen earlier in the post-war period. Whilst the effective trade of wage moderation for sustained investment never actually operated as neatly as models

28 T. Bergholm, A. Bieler: Globalization and the erosion of the Nordic model: A Swedish-Finnish comparison, in: European Journal of Industrial Relations, Vol. 19, No. 1, 2013, pp. 55-70. 
suggested, Nordic economies were able to sustain relatively strong investment performance even into the 1970 s and 1980s. It is not clear that strongly corporatist economies had any particular advantage during the 1990s at ensuring orderly adjustment and maintaining investment and growth over the medium term. Indeed, the financial liberalisation boom and bust in the late 1980s and early 1990s disrupted corporatist relations in these countries. The subsequent recession led to high unemployment in Finland and Sweden. In the post-war period, Nordic economies had relatively limited financial systems and relatively closed external capital accounts. But financial liberalisation since the 1980s has increased the external capital options, a development that has undermined the social corporatist bargain that had previously led to high investment.

There are some notable aspects of the Nordic model that may be worth highlighting. Recent research into weak productivity performance since the financial crisis has highlighted the importance of the gap between the most productive firms and the rest. While wage compression may only be one possible mechanism to promote the relative growth of productive firms, it does appear to be effective in promoting productivity growth in Nordic economies. Second, although Swedish unions' plans for a Wage-Earners Fund were never realised in their radical conception, public wealth remains high not just in Norway, with its sovereign wealth fund, but also in Finland and Sweden. ${ }^{29}$ This is in marked contrast to the decline in public capital amongst other developed economies, as highlighted in the 2018 World Inequality Report. ${ }^{30}$ The general rise in the capital share has already been noted; typically this tends to raise inequality given the concentration of capital ownership. Greater collective capital ownership is one possible means of mitigating this.

Finally, the Nordic economies themselves have still exhibited what Offer and Söderberg term the "market turn" away from social democratic systems of collective provision towards market-based systems based on personal accumulation of financial assets (particularly property). ${ }^{31}$ Nordic economies have amongst the highest household debt-to-income ratios, albeit offset by high levels of household wealth. The global financial crisis has raised questions over the sustainability of such systems.

29 Y. Hasselberg, H. OhIsson: Collective Wealth Formation: Conflict and Compromise in Sweden, 1950-2000, in: P. Hudson, K. Tribe (eds.): The Contradictions of Capital in the Twenty-first Century: The Piketty Opportunity, Newcastle 2016, Agenda Publishing, pp. 109130.

30 F. Alvaredo, L. Chancel, T. Piketty, E. Saez, G. Zucman: World Inequality Report 2018, World Inequality Lab, pp. 154-195.

31 A. Offer, G. Söderberg: The Nobel factor: The prize in economics, social democracy, and the market turn, Princeton NJ 2016, Princeton University Press. 